\title{
Yayasan Pendidikan Islam Tompobulu, 1962-2010
}

\author{
Resky Ananda, Mustari Bosra, Ahmadin \\ Prodi Pendidikan Sejarah Fakultas Ilmu Sosial Universitas Negeri Makassar \\ anandha_resky@yahoo.com
}

\begin{abstract}
Abstrak
Penelitian ini bertujuan untuk mengetahui latar belakang, perkembangan, serta dampak keberadaan Yayasan Pendidikan Islam Tompobulu di Kecamatan Tompobulu, Kabupaten Gowa. Penelitian ini menggunakan metode penelitian sejarah yang terdiri atas empat tahapan yaitu: heuristik, kritik sumber, interpertasi, dan historiografi. Data untuk penelitian ini diperoleh dari situs resmi dari Badan Pusat Statistik Kecamatan Tompobulu, serta hasil wawancara dengan beberapa pihak yang berperan penting dalam Yayasan Pendidikan Islam Tompobulu. Beberapa sumber buku yang terkait dengan dengan kajian penulis yang diperoleh dari Perpustakaan Kota Makassar, Perpustakaan Umum Universitas Negeri Makassar, Perpustakaan Prodi Pendidikan Sejarah, serta beberapa situs di internet. Hasil penelitian ini menunjukkan bahwa keberadaan Yayasan Pendidikan Islam Tompobulu memiliki peranan penting dalam dunia pendidikan di Kecamatan Tompobulu. Yayasan ini berdiri sebagai solusi bagi masyarakat Tompobulu yang mengalami kendala dalam pendidikan. Seiring dengan berjalannya waktu, maka yayasan ini juga mengalami perkembangan mengikuti zaman, sehingga madrasah-madrasah naungan Yayasan Pendidikan Islam Tompobulu mampu bersaing dengan sekolah-sekolah lain yang ada di Kabupaten Gowa, khususnya di Kecamatan Tompobulu. Yayasan ini memiliki peranan yang besar dalam mencerdaskan serta meningkatkan mutu perekonomian masyarakat Kecamatan Tompobulu.
\end{abstract}

\section{Kata kunci : Yayasan, Pendidikan Islam, Tompobulu}

\section{Abstract}

This research and writing aims to determine the background, development, and impact of the existence of the Tompobulu Islamic Education Foundation in Tompobulu District, Gowa Regency. This study uses a historical research method which consists of four stages, namely: heuristics, source criticism, interpretation, and historiography. Data for this study were obtained from the official website of the Central Statistics Agency of Tompobulu District, as well as the results of interviews with several parties who played an important role in the Tompobulu Islamic Education Foundation. Several book sources related to the study of writers obtained from the Makassar City Library, Makassar Public University Public Library, Historical Education Study Library, and several sites on the internet. The results of this study indicate that the existence of the Tompobulu Islamic Education Foundation has an important role in the world of education in Tompobulu District. This foundation stands as a solution for the people of Tompobulu who experience obstacles in education. As time goes by, the foundation also develops with the times, so that the Islamic Education Foundation Tompobulu madrassas are able to compete with other schools in Gowa Regency, especially in Tompobulu District. This foundation has a large role in educating and improving the economic quality of the people of Tompobulu Distric.

\section{Keywords: Foundation, Islamic Education, Tompobulu}

\section{A. Pendahuluan}


Pendidikan memiliki peranan penting dalam suatu negara, karena pendidikan menjamin kualitas hidup sumber daya manusia. Sebagai sesuatu yang berperan sebagai penjamin kualitas hidup suatu negara, maka sudah sepantasnya pendidikan harus dikembangkan agar selalu dapat menyesuaikan diri dengan perkembangan ilmu pengetahuan dan teknologi yang semakin berkembang dari zaman ke zaman. Di negara kita, pendidikan merupakan salah satu bidang pembangunan yang pelaksanaannya berada dalam naungan Kementerian Pendidikan dan Kebudayaan Nasional.

Di Indonesia, pendidikan terbagi atas beberapa jenjang. Dimulai dengan TK (taman kanak-kanak), yaitu pendidikan anak usia dini (usia enam tahun ke bawah). SD (sekolah dasar), yaitu jenjang paling dasar pada pendidikan formal yang ditempuh selama 6 tahun pada umumnya. SLTP (sekolah lanjutan tingkat pertama), yaitu jenjang pendidikan dasar pada pendidikan normal setelah lulus SD yang umumnya ditempuh dalam 3 tahun. SLTA (sekolah lanjutan tingkat atas), yaitu jenjang pendidikan setelah SLTP, jenjang ini juga ditempuh dalam waktu 3 tahun waktu normal. Jenjang yang terakhir yakni Perguruan Tinggi, yaitu satuan penyelenggara pendidikan tinggi. Pendidikan itu sendiri sejatinya terjadi pada tiga lapisan lingkungan sosial, yaitu keluarga, masyarakat luas, dan sekolah. Setiap lingkungan ini memiliki peran yang berbeda. Lingkungan keluarga berfungsi sebagai alat pembinaan potensi spiritual. Di lingkungan masyarakat berpusat pada potensi moral. Sedangkan lingkungan sekolah, sasaran kegiatan pendidikan adalah bimbingan potensi intelektual, untuk mendorong perkembangan kreativitas, kecakapan, dan kemampuan hidup.

Pendidikan Islam merupakan pewarisan dan perkembangan budaya manusia yang bersumber dan berpedoman ajaran Islam sebagaimana yang termaktub dalam Al-qur'an dan terjabar dalam Sunnah Rasul, yang dimaksudkan adalah dalam rangka terbentuknya kepribadian utama menurut ajaran-ajaran Islam. (marimba, 1984)

Sejarah perkembangan dan pertumbuhan pendidikan Islam di Indonesia antara lain ditandai dengan adanya lembaga-lembaga pendidikan Islam yang amat bervariasi, yang antara satu dan lainnya memiliki hubungan substansial dan fungsional. (Data, 2001)

Salah satu lembaga pendidikan Islam yang telah memperlihatkan peranannya sejak dulu adalah yayasan. Keberadaan yayasan di Indonesia telah dikenal sejak zaman pemerintahan Hindia Belanda yang dikenal dengan sebutan "stiching". (Wijaya, 2002)

Yayasan adalah suatu badan hukum yang mempunyai maksud dan tujuan bersifat sosial, keagamaan dan kemanusiaan, didirikan dengan memperhatikan persyaratan formal yang ditentukan dalam undang-undang. $\mathrm{Di}$ Indonesia, yayasan diatur dalam UndangUndang Nomor 28 Tahun 2004 tentang Perubahan atas Undang-Undang Nomor 16 Tahun 2001 tentang Yayasan. Rapat paripurna DPR pada tanggal 7 September 2004 menyetujui undang-undang ini, dan Presiden Republik Indonesia Megawati Soekarnoputri mengesahkannya pada tanggal 6 Oktober 2004. (Anon., 2019)

Di Kecamatan Tompobulu (dekade tahun 1962 belum dimekarkan) Kabupaten Gowa, telah didirikan madrasah-madrasah Pendidikan Agama yang berada dalam naungan Yayasan Pendidikan Agama Tompobulu (YAPIT) Malakaji. Madrasahmadrasah ini terdiri atas: 1 Pendidikan Guru Agama (PGA) enam tahun, 2 Pendidikan Guru Agama (PGA) empat tahun, yang kemudian disusul oleh sepuluh Madrasah Ibtidaiyah, dengan Departemen Agama (Depag) Kabupaten Gowa sebagai penanggung jawab dari Yayasan ini. (Sahing, 2018)

Yayasan ini didirikan atas dasar kenyataan yang dialami oleh masyarakat dataran tinggi Kecamatan Tompobulu Kabupaten Gowa yang ingin bersekolah 
untuk ke jenjang tingkat lanjutan pada dekade tahun 1960-an. Di wilayah Tompobulu belum ada sekolah lanjutan. Sekolah lanjutan hanya ada di Ujung Pandang (sekarang Makassar). Jarak dari Kecamatan Tombobulu adalah $147 \mathrm{KM}$ dari Sungguminasa, ibukota Kabupaten Gowa dan itu artinya $157 \mathrm{KM}$ dari Ujung Pandang, sehingga masyarakat yang ingin melanjutkan pendidikan lanjutan, mereka harus merantau untuk bersekolah di Ujung pandang. Banyak alumni dari sekolahsekolah dasar yang ingin melanjutkan sekolah tetapi mengalami kesulitan untuk mendapatkan tempat tinggal, transportasi, dan biaya hidup. (Anon., 2017)

Dari kenyataan tersebut di atas, maka beberapa tokoh masyarakat berinisiatif untuk membangun sebuah yayasan di dataran tinggi Tompobulu Kabupaten Gowa. Pembangunan ini dipelopori oleh H. Ahmad, beliau pula yang menjabat sebagai ketua yayasan dari tahun berdirinya hingga tahun 2010.

Yayasan Pendidikan Islam Tompobulu merupakan lembaga pendidikan agama yang terus mengembangkan kiprahnya dalam pembangunan pendidikan agama melalui peningkatan kualitas sumber daya manusia pada masyarakat dataran tinggi Tompobulu dan sekitarnya. Keberadaan yayasan ini di Kecamatan Tompobulu telah berkembang melalui beberapa tahapan. Apabila pada masa awalnya penyelenggaraan proses belajar-mengajar dilakukan di bawah kolong rumah masyarakat dengan sarana yang seadanya, maka saat ini madrasah-madrasah naungan Yayasan Pendidikan Islam Tompobulu telah memiliki fasilitas serta sarana dan prasarana yang memadai dan mendukung proses kegiatan belajar-mengajar. (Idris, 2018)

Hingga saat ini, keberadaan dan perkembangan Yayasan Pendidikan Islam Tompobulu telah menunjukkan kiprah dan eksistensinya dalam dunia Pendidikan Agama, dalam hal ini Agama Islam di Kabupaten Gowa khususnya dataran tinggi Tompobulu dan sekitarnya. Hal inilah yang mendasari penulis untuk mengkaji "Yayasan Pendidikan Islam Tompobulu dalam kurun waktu tahun 1962 hingga tahun 2010"

\section{B. Metode Penelitian}

Dalam suatu penelitian, penggunaan metode sangatlah penting. Hal ini bertujuan untuk memastikan keotentikan dan mempermudah dalam memahami fenomena dalam suatu penelitian. Dalam sejarah, metode yang digunakan untuk meneliti adalah metode penelitian sejarah. Metode sejarah dapat diartikan sebagai cara atau prosedur yang sistematis dalam merekonstruksi masa lampau. Penelitian sejarah yang pada dasarnya adalah penelitian terhadap sumber-sumber sejarah, merupakan implementasi dari tahapan kegiatan yang tercakup dalam metode sejarah, yaitu heuristik, kritik, interpretasi, dan historiografi. Tahapan kegiatan yang disebut terakhir sebenarnya bukan kegiatan penelitian, melainkan kegiatan penulisan sejarah (penulisan hasil penelitian).

\section{a. Heuristik}

Sebelum menentukan teknik pengumpulan sumber sejarah, pertamatama yang harus dilakukan adalah memahami bentuk dari sumber sejarah yang akan dikumpulkan. Penentuan ini akan berpengaruh pada tempat (di mana) atau siapa dan cara apa yang digunakan untuk memperoleh sumber sejarah.

Pertama, sumber tulisan yakni jejak masa lalu yang mengandung informasi dalam bentuk tulisan. Tulisan ini dapat berupa informasi pengetahuan dari tangan pertama atau sering disebut dengan informasi primer. Sumber primer ini pada umumnya dapat berupa arsip, catatan perjalanan, risalah sidang, surat keputusan, dan lain sebagainya. Sumber sejarah primer yang tertulis dalam sejarah biasanya berupa dokumen. Dokumen tersebut dapat diperoleh pada lembaga-lembaga khusus yang menangani atau menghimpun arsip atau koleksi perseorangan yang belum disimpan pada pada lembaga terkait. 
Contohnya adalah Arsip Nasional Republik Indonesia dan Perpustakaan Nasional di Jakarta dan di daerah. Khusus pengumpulan terakhir, perlu diketahui sejarawan atau peneliti bahwa tidak semua sumber arsip yang dibutuhkan dapat digandakan. Kedua, sumber tulisan yakni informasi tentang suatu peristiwa, baik yang disampaikan secara turun-temurun maupun langsung dari pelaku sejarah. Penggunaan oral tradition dalam karya penulisan sejarah apabila tidak ada sumber lisan langsung (oral history) maupun tulisan. Tehnik penggunaan sumber sumber lisan yang langsung pada pelaku sejarah biasa juga disebut dengan nama sejarah lisan. Penggunaan metode lisan dalam sejarah sangat penting, bagian-bagian yang tidak lengkap dalam bahan dokumen disusun melalui wawancara dengan para pelaku atau saksi sejarah. Dan pada tingkat yang mendasar, wawancara dapat merupakan kisah yang menghubungkan catatan-catatan tekstual tersebut. (Hamid, 2018)

Heuristik merupakan tahap awal dalam penelitian sejarah, yaitu mencari dan mengumpulkan sumber-sumber atau data yang berhubungan dengan topik yang akan diteliti. Dalam tahap pengumpulan data ini akan banyak menyita waktu, biaya, tenaga serta pikiran, karena penulis diwajibkan mencari sumber-sumber terkait penelitian yang dilakukan. (Sjamsuddin, 2012)

Heuristik adalah mencari dan mengumpulkan sumber-sumber sejarah yang terkait dengan dengan topik penelitian. Dapat juga diartikan sebagai kegiatan berupa penghimpunan jejak-jejak masa lampau., yakni peninggalan sejarah atau sumber apa saja yang dapat dijadikan informasi.

Heuristik merupakan tahap awal yang diarahkan pada pencarian pengumpulan sumber yang berkaitan dengan hal yang akan diteliti, dalam hal ini pengumpulan sumber terkait "Yayasan Pendidikan Islam Tompobulu". Heuristik dititikberatkan pada penelitian lapangan dan pengumpulan sumber berupa arsip/dokumen, buku, maupun informasi dari beberapa informan.
Pengumpulan sumber yang dilakukan oleh peneliti ada dua cara, yaitu:

\section{1) Penelitian pustaka}

Penelitian pustaka merupakan pengumpulan data-data atau sumber yang berkaitan dengan arsip, buku, hasil penelitian, jurnal, dan lain-lain. Sumber ini digolongkan sebagai sumber sekunder atau sumber pelengkap pengumpulan data yang memiliki kaitan dengan objek kajian yang ditulis oleh peneliti.

Data sekunder dari penelitian ini diperoleh dari Perpustakaan Jurusan Pendidikan Sejarah Universitas Negeri Makassar. Perpustakaan Umum Universitas Negeri Makassar, Perpustakaan Wilayah Kota Makassar, Badan Pusat Statistik (BPS) Kabupaten Gowa, Data Referensi Kementerian dan Kebudayaan (Kemdikbud), serta beberapa buku yang berkaitan dengan objek penelitian.

\section{2) Penelitian lapangan}

Dalam penelitian lapangan, peneliti menggunakan tehnik interview atau wawancara. Wawancara adalah upaya menggali informasi dari seseorang yang terlibat secara langsung dalam kegiatan. Wawancara dalam sejarah biasa pula disebut dengan Sejarah Lisan atau Oral History. Dengan metode wawancara, penulis mewawancarai beberapa tokoh yang berperan penting dalam perkembangan Yayasan Pendidikan Islam Tompobulu, yaitu mantan sekretaris Yayasan Pendidikan Islam Tompobulu, sekretaris Yayasan Pendidikan Islam Tompobulu sekarang, mantan bendahara Yayasan Pendidikan Islam Tompobulu, dan ketua Yayasan Pendidikan Islam Tompobulu.

\section{Kritik Sumber}

Setelah sumber dikumpulkan, maka tahap selanjutnya adalah kritik sumber. Kritik sumber, yaitu suatu tahap untuk mengetahui keabsahan suatu sumber atau data yang didapatkan. Kritik tersebut berupa kritik tentang otentitasnya (kritik eksternal) maupun kredibilitas isi (kritik internal). Kritik ini dilakukan ketika dan sesudah pengumpulan data berlangsung. 
Sumber sejarah yang telah dikritik menjadi data sejarah.

Kritik eksternal atau kritik luar dilakukan untuk meneliti keaslian sumber, yaitu apakah sumber tersebut valid, asli atau tiruan, sumber tersebut utuh dalam artian belum berubah. Kritik internal atau kritik dalam dilakukan untuk meneliti sumber yang berkaitan dengan masalah dalam penelitian dan penulisan.

\section{Interpretasi}

Setelah dilakukan kritik sumber, maka diketahui validasi dan akurasi data penelitian untuk kemudian merekonstruksi peristiwa yang terjadi. Interpretasi atau penafsiran dilakukan terhadap fakta sejarah yang diperoleh dalam bentuk penjelasan terhadap fakta tersebut seobjektif mungkin. Dalam interpretasi, fakta-fakta sejarah dapat diuraikan dan disatukan sehingga mempunyai makna yang berkaitan satu dengan yang lainnya.

Tidak semua fakta harus dimasukkan kedalam tulisan, tetapi harus dipilih mana yang relevan dengan mana yang tidak relevan dengan tema yang diangkat.

\section{Historiografi}

Langkah terakhir dalam penulisan ini yaitu historiografi, yang merupakan akhir dari segalanya. Sebab penulis sudah menangkap dan memahami sejarah sebagaimana yang terjadi. Tahap heuristik, kritik, dan interpretasi kemudian dielaborasi seingga menghasilkan sebuah penulisan sejarah.

Penulisan sejarah tidak hanya terbatas menjawab apa, siapa, kapan, dan bagaimana suatu peristiwa terjadi, melainkan suatu ekplanasi secara kritis dan mendalam tentang bagaimana dan mengapa peristiwa terjadi.

\section{Pembahasan}

\section{Latar Belakang Berdirinya Yayasan} Pendidikan Islam Tompobulu

Kecamatan Tompobulu terbentuk tahun 1960 berdasarkan kebijaksanaan Pemerintah Pusat di seluruh Wilayah Republik Indonesia diadakan Reorganisasi Distrik menjadi Kecamatan. untuk
Kabupaten Daerah Tingkat II Gowa yang terdiri dari 12 Distrik diubah menjadi 8 Kecamatan masing-masing:Kecamatan Tamalate dari Distrik Mangasa dan Tombolo,Kecamatan Panakkukang dari Distrik Pattallassang,Kecamatan Bajeng dari Distrik Limbung,Kecamatan Pallangga dari Distrik Limbung,Kecamatan Bontonompo dari Distrik Bontonompo,Kecamatan Tinggimoncong dari Distrik Parigi dan Tombolopao,Kecamatan Tompobulu dari Distrik Malakaji, Kecamatan Bontomarannu dari Distrik Borongloe, Manuju dan Borisallo.

Tompobulu merupakan salah satu kecamatan (daerah tingkat III) yang berada di wilayah Kabupaten Gowa, provinsi Sulawesi Selatan. Tompobulu beribukota di Malakaji. Berjarak sekitar $147 \mathrm{~km}$ dari Sungguminasa, ibukota Kabupaten Gowa. Merupakan daerah dataran tinggi, dengan rata-rata ketinggian 1000 meter DPL (di atas permukaan laut). (Anon., 2017)

Kecamatan Tompobulu memiliki batas daerah, yaitu: Kabupaten Sinjai pada sebelah utara, Kabupaten Jeneponto sebelah selatan,Kecamatan Biringbulu sebelah barat, Kabupaten Jeneponto di sebelah timur.

Terdapat beberapa akses mencapai kecamatan ini, antara lain:jalur PallanggaBungayya, jalur Palleko (Takalar)Biringbulu, dan jalur SungguminasaJeneponto.

Akses utama yang dipergunakan warga sejak puluhan tahun silam adalah akses terakhir. Yaitu jalan nasional yang menghubungkan Makassar ke Jeneponto, karena dua akses pertama kondisi jalannya masih kurang baik selain jalur itu dipenuhi tanjakan.

Kecamatan Tompobulu dibentuk berdasarkan Peraturan Daerah (Perda) Kabupaten Gowa Nomor 7 Tahun 2007 Tentang Pembentukan Kecamatan di Kabupaten Gowa. Kecamatan ini dibagi dalam enam desa dan dua kelurahan sebagai pembagian wilayah administratifnya.

Berikut nama desa dan kelurahan di kecamatan Tompobulu (Anon., 2017): 
Kelurahan Malakaji, Kelurahan Cikoro, Desa Datara, Desa Rampolemba, Desa Rappoala, Desa Tanete, Desa Bontobuddung, Desa Garing.

Kecamatan Tompobulu menurut Badan Pusat Statistik Kabupaten Gowa 2018 memiliki luas 132,54 km.Menurut Badan Pusat Statistik Kecamatan Tompobulu tahun 2018, jumlah penduduk Kecamatan Tompobulu adalah sebesar 28.704 jiwa yang terdiri dari laki-laki sebesar 13.840 jiwa dan perempuan sebesar 14.864 jiwa dengan jumlah Rumah Tangga 7.534. Kecamatan Tompobulu umumnya berprofesi sebagai petani padi/palawija dan perkebunan kopi, sedangkan sektor nonpertanian terutama bergerak pada lapangan usaha perdagangan besar dan enceran.

YAPIT Malakaji adalah singkatan dari Yayasan Pendidikan Islam Tompobulu. Pendiri dari yayasan ini adalah beberapa tokoh masyarakat Tompobulu yang berinisiatif untuk mendirikan sebuah sekolah di dataran tinggi Kecamatan Tompobulu. melihat banyak masyarakat yang masih kurang dalam hal pendidikan sehingga timbul ide untuk mendirikan suatu tempat pendidikan secara formal. Guna melahirkan generasi-generasi bangsa yang nantinya dapat bersaing di era pendidikan kedepannya, dan dengan adanya pendidikan mereka mampu untuk membangun daerahnya dengan mengeluarkan ide-ide atau gagasan yang dapat menunjang kehidupan bermasyarakat. Tokoh-tokoh tersebut, adalah: H. Ahmad, H. Badjidu, H. Nuhung D.S, H. Abdullah, H. Sander B.M, H. Hindi Nyonri', H. Sulaiman, dan Drs. Muchtar Waliati. Mereka kemudian berembuk untuk memikirkan apa yang seharusnya dilakukan sehingga masyarakat tompobulu dapat memiliki sistem pendidikan yang layak seperti halnya daerah-daerah lain tanpa harus keluar daerah untuk mengenyam pendidikan. Orang-orang inilah yang kemudian tergerak hatinya untuk mendirikan sebuah sarana pendidikan karena memikirkan nasib pendidikan anak-anak di Kecamatan
Tompobulu, dan niat baik mereka pun disambut baik oleh pemerintah setempat sehingga berdirilah sebuah yayasan pendidikan di kawasan Kecamatan Tompobulu, yaitu nama Yayasan Pendidikan Islam Tompobulu.

Sejak awal, sebuah yayasan didirikan bukan bertujuan untuk mencari suatu keuntungan, akan tetapi tujuannya tidak lebih untuk membantu atau meningkatkan kesejahteraan hidup orang banyak.

Melihat keadaan masyarakat Tompobulu yang terkendala dalam hal pendidikan, maka para tokoh masyarakat sepakat untuk mendirikan sebuah yayasan dengan pertimbangan yang menjadi dasar penentu arah tujuan dan kebijaksanaan pendidikan di Yayasan Pendidikan Islam Tompobulu, yaitu mengantisipasi masa depan dan dalam penyediaan guru agama yang berkualitas serta tokoh agama yang mumpuni. Dengan pertimbangan diatas, maka Yayasan Pendidikan Islam Tompobulu menentukan arah tujuan dan strategi kebijakan pendidikannya. Dengan adanya Yayasan Pendidikan Islam Tompobulu di Kecamatan Tompobulu, dapat meningkatkan mutu pendidikan masyarakat Kecamatan Tompobulu dan wilayah sekitarnya.

2. Profil Dan Dinamika Perkembangan Yayasan Pendidikan Islam Timpobulu

Setiap lembaga pastinya memiliki struktur organisasinya, begitu pula dengan Yayasan Pendidikan Islam Tompobulu atau biasa dikenal dengan sebutan YAPIT Malakaji. Dalam pelaksanaannya, Yayasan Pendidikan Islam Tompobulu memiliki struktur dan susunan pengurus.Yayasan Pendidikan Islam Tompobulu ini diurus oleh Dewan Pengurus yang beranggotakan paling sedikitnya 6 orang dan sebanyakbanyaknya 12 orang.

Pengangkatan dewan pengurus hanya dapat dilakukan dalam rapat tahunan anggota dewan pengurus, kecuali dewan pengurus pengurus berhenti karena alasan:Meninggal, Diberhentikan oleh dewan pengurus, dan Permintaan sendiri 
PATTINGALLOANG

(C) Jurnal Pemikiran Pendidikan dan Penelitian Kesejarahan

Yayasan Pendidikan Islam Tompobulu sebagai lembaga Pendidikan Agama yang berdiri tahun 1962, mula-mula mendirikan sekolah yang diberi nama Pendidkan Guru Agama atau disingkat PGA. PGA ini memiliki masa bakti bagi siswanya yaitu selama 4 tahun dalam menamatkan siswanya. Merupakan sekolah pertama naungan dari yayasan ini. PGA 4 tahun ini mulai dibuka dan menerima murid pada tahun 1962.

Yayasan Pendidikan Islam Tompobulu dalam mempertahankan eksistensinya, mendirikan madrasah-madrasah yang tersebar di wilayah Kecamatan Tompobulu. pembanggunan madrasah-madrasah tersebut berlangsung dari tahun 1962 hingga pada tahun 1979.

Kurikulum adalah salah satu komponen pada sistem pendidikan yang diselenggarakan oleh satuan pendidikan apa pun dan pada jenjang apa pun. Kurikulum juga merupakan bagian yang tak bisa tinggalkan oleh kesatuan sistem pendidikan yang dianut oleh Indonesia.Kurikulum yang digunakan oleh sekolah-sekolah naungan Yayasan Pendidikan Islam Tompobulu mengikuti kurikulum yang ditetapkan oleh Kementerian Departemen Agama Republik Indonesia. Dimana isinya hampir sama dengan kurikulum yang dikeluarkan oleh Kementerian Pendidikan dan Kebudayaan Republik Indonesia. Bedanya hanya terletak pada penambahan 5 mata pelajaran yakni mata pelajaran Fiqih, Al-Qur'an Hadits, Bahasa Arab, Akidah Akhlak, dan Sejarah Kebudayaan Islam.

Sebagai lembaga pendidikan yang didirikan untuk menangani masalah kendala pendidikan di Kecamatan Tompobulu, maka Yayasan Pendidikan Islam Tompobulu mendapatkan sambutan yang hangat dari tokoh dan masyarakat setempat. Yayasan Pendidikan Islam Tompobulu adalah sebuah lembaga pendidikan yang menyelenggarakan pendidikan untuk ketenagakerjaan pendidikan islam.

\section{Dampak Keberadaan Yayasan Pendidikan Islam Tompobulu \\ Seiring dengan perkembangannya,} Yayasan Pendidikan Islam Tompobulu telah menunjukkan peran yang cukup besar, dengan adanya Yayasan Pendidikan Islam Tompobulu ini, telah mampu menumbuhkan kesadaran dan pengertian kepada masyarakat Tompobulu tentang pentingnya pendidikan bagi semua warga masyarakat. Sebelum berdirinya yayasan ini, sebagian masyarakat kurang memahami tentang pentingnya pendidikan demi keberlangsungan hidupnya dikemudian hari.

Pertumbuhan ekonomi merupakan salah satu ukuran keberhasilan suatu negara. Pertumbuhan ekonomi akan dipengaruhi oleh beberapa faktor, antara lain tenaga kerja modal, dan kemajuan teknologi. Tenaga kerja yang mempengaruhi pertumbuhan ekonomi adaah dari segi jumah (kuantitas) dan kualitasnya. Kualitas tenaga kerja akan dipengaruhi oleh beberapa hal antara lain pendidikan dan kesehatan. Di antara berbagai aspek ini, pendidikan dianggap yang memiliki peranan penting dalam menentukan kualitas hidup manusia.

\section{Kesimpulan}

Berdasarkan hasil pembahasan yang telah diuraikan sebelumnya, maka kesimpualan yang dapat diangkat adalah sejarah berdirinya Yayasan Pendidikan Islam Tompobuluyaitu Pendiri dari yayasan ini adalah beberapa tokoh masyarakat Tompobulu yang berinisiatif untuk mendirikan sebuah sekolah di dataran tinggi Tompobulu. melihat banyak masyarakat yang masih kurang dalam hal pendidikan sehingga timbul ide untuk mendidirkan suatu tempat pendidikan secara formal. Guna melahirkan generasigenerasi bangsa yang nantinya dapat bersaing di era pendidikan kedepannya.

Perkembangan Yayasan Pendidikan Islam Tompobulu adalah Yayasan Pendidikan Islam Tompobulu dalam mempertahankan kiprahnya kemudian 
mendirikan madrasah-madrasah yang tersebar di wilayah Kecamatan Tompobulu yang berlangsung dari tahun 1962-2010.

Dampak Keberadaan Yayasan Pendidikan Islam Tompobulu adalah Dengan adanya yayasan ini, masyarakat Tompobulu mendapatkan fasilitas pendidikan agama yang dekat dengan tempat tinggal mereka. Hal ini membuat masyarakat Tompobulu tidak perlu lagi merantau ke Makassar atau ke kabupaten tetangga untuk menimbah ilmu. Dan juga masyarakat Tompobulu mendapatkan pemahaman agama yang baik, melalui ceramah-ceramah dari alumni maupun siswa dari Yayasan Pendidikan Islam Tompobulu.

\section{DAFTAR PUSTAKA}

Anon., 2017. Badan Pusat Statistik. [Online]

[Accessed 11 Januari 2019].

Anon., 2017. Badan Statistik Kabupaten Gowa.

[Online]

[Accessed 11 Januari 2019].

Anon., 2017. Badan Statistik Kabupaten

Gowa.

[Online]

[Accessed 11 Januari 2019].

Anon.,

2019.

https://id.wikipedia.org/wiki/Yayasa

$n$.

[Online]

[Accessed 11 Januari 2019].

Data, A., 2001. Sejarah Pertumbuhan dan

Perkembangan Lembaga-Lembaga

Pendidikan Islam di Indonesia.

Jakarta: Gramedia Widiasarana

Indonesia.

Hamid, A. R., 2018. Pengantar Ilmu

Sejarah. Makassar: Rayhan

Intermedia.

Idris, M., 2018. Sarana dan Prasana

Yayasan Pendidikan Islam

Tompobulu [Interview] $\quad(27$

September 2018).

Kosim, M., 2007. Sejarah Perkembangan

Lembaga Pendidikan Guru Agama

Islam Negeri Jenjang Pertama.

Tadris, Volume 2, p. 88.
Marimba, a. D., 1984. Filsafat Pendidikan Islam. Bandung: Al-Ma'arif.

Muzakkir, 2015. Pendidikan Islam Masa Orde Lama dan Masa Orde Baru. Al-Fatih, p. 90.

Prasetya, R., 2012. Yayasan dalam Teori Praktik. Surabaya: Sinar Grafika.

Sahing, M. A., 2018. Kabupaten Gowa [Interview] (27 September 2018).

Sjamsuddin, H., 2012. Metodologi Sejarah. Yogyakarta: Ombak.

Wijaya, G., 2002. Yayasan di Indonesia Sesuatu Panduan Komprehensif. Jakarta: Elex Media Komputindo. 